\title{
ANALISIS FAKTOR-FAKTOR YANG MEMENGARUHI WAKTU KELULUSAN MAHASISWA DENGAN MENGGUNAKAN METODE GOMPIT (Studi Kasus: Mahasiswa Fakultas MIPA Universitas Udayana)
}

\author{
Ni Komang Deby Ariani ${ }^{1}$, I Wayan SumarJaya ${ }^{2}$, \\ TJOKORDA BAGUS OKA ${ }^{3}$ \\ 1,2,3 Jurusan Matematika FMIPA Universitas Udayana, Bukit Jimbaran-Bali \\ e-mail: ${ }^{1}$ deby.ariani@yahoo.com, ${ }^{2}$ sumarjaya@unud.co.id, ${ }^{3}$ tjokordabagusoka@gmail.com
}

\begin{abstract}
The aims of this research analyzed the factors affecting the period of the students' graduation based on GPA at Faculty of Mathematics and Natural Science, Udayana University by using gompit regression. This data strongly indicates unbalanced between students who graduated on time and students who graduated not on time. The result of this study indicates that the graduation of the students based on the GPA categorization satisfied all of the independent variables was not significant. Meanwhile, for the graduation of the students based on the GPA categorization was highly satisfied. There are four dependent variables which are significant, such as: gender, study program, region, and the final assignment accomplishment period. Moreover, for the students' graduation based on the GPA categorization with praises, there were two independent variables which were significant: region and the final assignment accomplishment period.
\end{abstract}

Keywords: gompit method, graduate point average (GPA), students' graduation period.

\section{Pendahuluan}

Pendidikan merupakan sejumlah pengalaman dari seseorang atau kelompok untuk dapat memahami sesuatu yang sebelumnya tidak dipahami (Ambarjaya, [1]). Semakin tinggi pendidikan seseorang, maka semakin banyak peluang untuk mendapatkan pekerjaan, karena persyaratan untuk mendapatkan pekerjaan umumnya dilihat dari latar belakang pendidikan. Pendidikan yang dimaksud dalam hal ini adalah pendidikan di perguruan tinggi. Dalam hal ini, mahasiswa diharapkan memperhatikan syarat-syarat yang harus dilaksanakan seperti menuntaskan studi yang telah ditentukan oleh perguruan tinggi atau universitas.

Mahasiswa yang menempuh program S1 diharapkan memperhatikan ketepatan waktu kelulusan. Tetapi sampai saat ini mahasiswa Fakultas MIPA belum sepenuhnya mampu menuntaskan studi dalam waktu kurang dari atau sama

\footnotetext{
${ }^{1}$ Mahasiswa Jurusan Matematika FMIPA Universitas Udayana

${ }^{2,3}$ Staf Pengajar Jurusan Matematika FMIPA Universitas Udayana
} 
dengan empat tahun. Oleh karena itu, perlu dilakukan analisis faktor-faktor yang memengaruhi waktu kelulusan mahasiswa di Fakultas MIPA. Metode yang dapat digunakan adalah metode gompit. Metode gompit digunakan karena data pada variabel tidak bebas memiliki data yang berskala kategorik, khususnya dikotomi yaitu mahasiswa yang lulus tepat waktu bernilai 1 dan mahasiswa yang lulus tidak tepat waktu bernilai 0 , serta memiliki kecenderungan yang tidak sebanding antara mahasiswa yang lulus tepat waktu dengan mahasiswa yang lulus tidak tepat waktu.

Tujuan dari penelitian ini adalah menganalisis faktor-faktor yang memengaruhi waktu kelulusan mahasiswa berdasarkan IPK Fakultas MIPA Universitas Udayana dengan menggunakan metode gompit.

\section{Regresi Gompit}

Variabel tak bebas mengambil dua nilai atau pilihan di antara dua alternatif (Binary dependent variable Models). Binary dependent variabel yang berdasarkan pada distribusi Gompertz dikenal dengan gompit. Model gompit (complementary log-log) adalah asimetris di sekitar nol (Guris et al., [2]). Bentuk dari distribusi Gompertz adalah (Wu et al., [5]):

$$
f(x)=\left\{\begin{array}{c}
\lambda e^{m x} \exp \left\{-\frac{\lambda}{m}\left(e^{m x}-1\right)\right\}, \text { untuk } x>0 \\
0, \text { lainnya }
\end{array}\right.
$$

dengan $m>0$ dan $\lambda>0$ adalah parameter. Jika $\beta$ merupakan vektor parameter, $x$ merupakan vektor variabel pendukung, $g$ adalah fungsi $P$ yang diasumsikan berhubungan dengan variabel pendukung secara linear, maka model-model Binary dependent variabel untuk metode gompit dapat dilihat pada Tabel 1 (Guris et al., $[2])$.

Tabel 1. Binary Dependent Variabel Models

\begin{tabular}{|c|c|}
\hline Model & Gompit (complementary log-log) \\
\hline Functional form & $\mathrm{C}(\quad)$ \\
\hline Probability $p(y=1 \mid x)$ & $\mathrm{C}(x \beta)=1-\exp (-\exp (x \beta))$ \\
\hline Link function & $g\left(P_{i}\right)=\ln \left(-\ln \left(1-\mathrm{P}_{\mathrm{i}}\right)\right)$ \\
\hline Marginal effect & $\exp (-\exp (x \beta)) \exp (x \beta) \beta_{j}$ \\
\hline Distribution & $\mathrm{Gompertz}$ \\
\hline Mean & $-\gamma$ \\
\hline Variance & $\frac{P^{2}}{6}$ \\
\hline
\end{tabular}

Sumber: Guris, et al., (2011)

untuk menduga parameter dalam regresi gompit digunakan metode kemungkinan maksimum (method of maximum likelihood) (Ismail, [4]). 


\section{Metode Penelitian}

Data yang digunakan dalam penelitian ini adalah data sekunder yang berupa data banyaknya mahasiswa yang lulus dari Fakultas MIPA Universitas Udayana pada periode Februari 2010 sampai dengan Maret 2013 dengan jumlah sampel sebanyak 740 responden. Variabel-variabel yang digunakan dalam penelitian ini dibagi menjadi dua yaitu variabel bebas dan variabel tidak bebas. Variabel bebas yang digunakan adalah jenis kelamin $\left(X_{1}\right)$, jurusan $\left(X_{2}\right)$, jalur masuk $\left(X_{3}\right)$, daerah asal $\left(X_{4}\right)$, asal SMA $\left(X_{5}\right)$, dan lama pengerjaan tugas akhir $\left(X_{6}\right)$. Sedangkan variabel tidak bebas pada penelitian ini adalah kelulusan mahasiswa dengan kategori tepat waktu yang bernilai 1 dan tidak tepat waktu yang bernilai 0 .

Adapun tiga langkah yang dikerjakan dalam penelitian ini adalah mengubah data menjadi data kategorik (variabel tidak bebas dan variabel bebas), melakukan uji simultan, dan uji parsial. Setelah melakukan uji simultan dan uji parsial, maka akan diperoleh estimasi model gompit. penelitian ini menggunakan software spss 20.0

\section{Hasil dan Pembahasan}

Uji simultan variabel bebas terhadap variabel tidak bebas menggunakan hipotesis (Intansari et al., [3]):

$$
\begin{aligned}
& H_{0}: \beta_{1}=\beta_{2}=\cdots=\beta_{k}=0 \\
& H_{1}: \text { minimal (paling sedikit) ada satu } \beta_{j} \neq 0, \text { dengan } j=1,2, \ldots, k
\end{aligned}
$$

dengan taraf signifikan adalah 0,05. Apabila $p$-value $<\alpha$, maka tolak $H_{0}$, hal ini berarti paling sedikit ada satu variabel bebas yang berpengaruh signifikan terhadap variabel tidak bebas atau terhadap waktu kelulusan mahasiswa, selanjutnya apabila $p$-value $>\alpha$, maka terima $H_{0}$, hal ini berarti tidak ada variabel bebas yang berpengaruh terhadap waktu kelulusan mahasiswa. Uji signifikansi variabel bebas secara simultan melalui uji Khi Kuadrat (Chi Squares) dapat dilihat pada Tabel 2.

Tabel 2. Uji Signifikansi Variabel Bebas secara Simultan

\begin{tabular}{|l|c|c|c|c|c|}
\hline $\begin{array}{l}\text { Uji Signifikansi } \\
\text { Variabel Bebas } \\
\text { secara Simultan }\end{array}$ & Model & $\begin{array}{c}\mathbf{- 2 ~ L o g} \\
\text { Likelihood }\end{array}$ & $\begin{array}{c}\text { Chi- } \\
\text { Square }\end{array}$ & df & Sig. \\
\hline $\begin{array}{l}\text { Berdasarkan IPK } \\
\text { Memuaskan }\end{array}$ & Intercept Only & 26,615 & & & \\
\cline { 2 - 6 } $\begin{array}{l}\text { Berdasarkan IPK } \\
\text { Sangat Memuaskan }\end{array}$ & Intercept Only & 66,310 & 5,305 & 6 & 0,505 \\
\cline { 2 - 6 } $\begin{array}{l}\text { Berdasarkan IPK } \\
\text { dengan Pujian }\end{array}$ & Intercept Only & 870,9999 & 94,655 & 6 & 0,000 \\
\cline { 2 - 6 } & Final & 63,292 & 25,918 & 6 & 0,000 \\
\hline
\end{tabular}

Sumber: Data diolah, 2013

Pada Tabel 2 menunjukkan bahwa uji signifikansi variabel bebas secara simultan berdasarkan IPK memuaskan, nilai $p$-value $=0,505>0,05$, yang 
berarti terima $H_{0} . H_{0}$ diterima artinya variabel bebas secara bersama-sama (simultan) tidak berpengaruh signifikan terhadap variabel tidak bebas atau waktu kelulusan mahasiswa, sedangkan uji signifikansi variabel bebas secara simultan berdasarkan IPK sangat memuaskan dan berdasarkan IPK dengan pujian, nilai $p$-value $=0,000<0,05$, yang berarti tolak $H_{0}$. Hal ini berarti paling sedikit ada satu variabel bebas yang berpengaruh signifikan terhadap waktu kelulusan mahasiswa. Estimasi pengujian variabel penelitian secara parsial berdasarkan IPK dapat dilihat pada Tabel 3, 4, dan 5.

Tabel 3. Estimasi Pengujian Variabel Penelitian secara Parsial (IPK Kategori Memuaskan)

\begin{tabular}{|c|c|c|l|}
\hline Variabel Bebas & Estimasi & $\boldsymbol{p}$-value & Signifikansi \\
\hline Kostanta & 0,461 & 0,852 & \\
\hline$X_{1}$ & 0,030 & 0,960 & Tidak signifikan \\
\hline$X_{2}$ & 0,351 & 0,321 & Tidak signifikan \\
\hline$X_{3}$ & $-0,200$ & 0,784 & Tidak signifikan \\
\hline$X_{4}$ & $-0,649$ & 0,200 & Tidak signifikan \\
\hline$X_{5}$ & $-0,381$ & 0,489 & Tidak signifikan \\
\hline$X_{6}$ & $-0,009$ & 0,821 & Tidak signifikan \\
\hline
\end{tabular}

Sumber: Data diolah, 2013

Berdasarkan Tabel 3, dari enam variabel bebas yang diamati, keseluruhan variabel bebas tidak signifikan ( $p$-value > 0,05) terhadap waktu kelulusan mahasiswa.

Tabel 4. Estimasi Pengujian Variabel Penelitian secara Parsial (IPK Kategori Sangat Memuaskan)

\begin{tabular}{|c|c|c|l|}
\hline Variabel Bebas & Estimasi & $\boldsymbol{p}$-value & \multicolumn{1}{|c|}{ Signifikansi } \\
\hline Kostanta & $-1,126$ & 0,011 & \\
\hline$X_{1}$ & 0,697 & 0,000 & Signifikan \\
\hline$X_{2}$ & $-0,099$ & 0,015 & Signifikan \\
\hline$X_{3}$ & $-0,188$ & 0,137 & Tidak signifikan \\
\hline$X_{4}$ & $-0,899$ & 0,000 & Signifikan \\
\hline$X_{5}$ & 0,277 & 0,076 & Tidak signifikan \\
\hline$X_{6}$ & $-0,115$ & 0,000 & Signifikan \\
\hline
\end{tabular}

Sumber: Data diolah, 2013

Tabel 4 menunjukkan bahwa, dari enam variabel bebas yang diamati, terdapat empat variabel bebas yang signifikan $(p$-value $<0,05)$ terhadap waktu kelulusan mahasiswa, yaitu: $\left(X_{1}\right),\left(X_{2}\right),\left(X_{4}\right)$, dan $\left(X_{6}\right)$. Estimasi model gompit dari kelulusan mahasiswa berdasarkan IPK sangat memuaskan yaitu:

$$
\ln \left(-\ln \left(1-P_{i}\right)\right)=-1,126+0,697 \mathrm{X}_{1}-0,099 \mathrm{X}_{2}-0,899 \mathrm{X}_{4}-0,115 \mathrm{X}_{6}
$$


Tabel 5. Estimasi Pengujian Variabel Penelitian secara Parsial (IPK Kategori dengan Pujian)

\begin{tabular}{|c|c|c|l|}
\hline Variabel Bebas & Estimasi & $\boldsymbol{p}$ - value & \multicolumn{1}{|c|}{ Signifikansi } \\
\hline Kostanta & $-5,657$ & 0,014 & \\
\hline$X_{1}$ & 0,046 & 0,940 & Tidak signifikan \\
\hline$X_{2}$ & $-0,267$ & 0,096 & Tidak signifikan \\
\hline$X_{3}$ & 0,359 & 0,512 & Tidak signifikan \\
\hline$X_{4}$ & $-1,683$ & 0,017 & Signifikan \\
\hline$X_{5}$ & $-0,147$ & 0,829 & Tidak signifikan \\
\hline$X_{6}$ & $-0,432$ & 0,002 & Signifikan \\
\hline
\end{tabular}

Sumber: Data diolah, 2013

Selanjutnya perhatikan Tabel 5. Tabel 5 menunjukkan bahwa, dari enam variabel bebas yang diamati, terdapat dua variabel bebas yang berpengaruh secara signifikan ( $p$-value $<0,05)$ terhadap waktu kelulusan mahasiswa, yaitu daerah asal $\left(X_{4}\right)$, dan lama pengerjaan tugas akhir $\left(X_{6}\right)$. Estimasi model gompit dari kelulusan mahasiswa berdasarkan IPK dengan pujian yaitu:

$$
\ln \left(-\ln \left(1-P_{i}\right)\right)=-5,657-1,683 \mathrm{X}_{4}-0,432 \mathrm{X}_{6}
$$

\section{Kesimpulan}

Berdasarkan hasil dari uji simultan dan uji parsial, maka dapat ditarik kesimpulan mengenai faktor-faktor yang memengaruhi waktu kelulusan mahasiswa berdasarkan IPK, yaitu: untuk kelulusan mahasiswa berdasarkan IPK dengan kategori memuaskan, diperoleh bahwa tidak ada faktor-faktor (variabel bebas) yang berpengaruh terhadap waktu kelulusan mahasiswa, sedangkan untuk kelulusan mahasiswa berdasarkan IPK kategori sangat memuaskan faktor-faktor yang memengaruhi waktu kelulusannya adalah jenis kelamin, jurusan, daerah asal, dan lama pengerjaan tugas akhir. Selanjutnya untuk kelulusan mahasiswa berdasarkan IPK kategori dengan pujian, faktor-faktor yang memengaruhi adalah daerah asal dan lama pengerjaan tugas akhir.

\section{Daftar Pustaka}

[1] Ambarjaya, Beni S. 2012. Psikologi Pendidikan dan Pengajaran. CAPS: Yogyakarta.

[2] Guris, S., Caglayan, E., dan Un, T. 2011. "Estimating of Probability of Home - Ownership in Rural and Urban Areas: Logit, Probit, and Gompit Model". European Journal of Social Sciences. 21 (3): 405 - 411.

[3] Intansari, I. A. S., Purnami, S. W., dan Wulandari, S. P. 2012. "Klasifikasi Pasien Hasil Pap Smear Test sebagai Pendeteksi Awal Upaya Penanganan Dini pada Penyakit Kanker Serviks di RS. "X" Surabaya dengan Metode Bagging Logistic Regression”. Jurnal Sains dan Seni ITS. 1 (1): 277 - 282. 
[4] Ismail, A.A. 2006. "On the Optimal Design of Step-Stress Partially Accelerated Life Test for Gompertz Distribution with Type-I Censoring". InterStat Journal, June. 1-15.

http://interstat.statjournals.net/YEAR/2006/articles/0606001.pdf. Diakses pada tanggal 4 maret 2013, pukul 12:07.

[5] Wu, S. J., Chang, C.T., dan Tsai, T.R. 2003. "Point and Interval Estimations for the Gompertz Distribution Under Progressive Type-II Censoring". Metron-International Journal of Statistics. 61 (3): 403 - 418. 